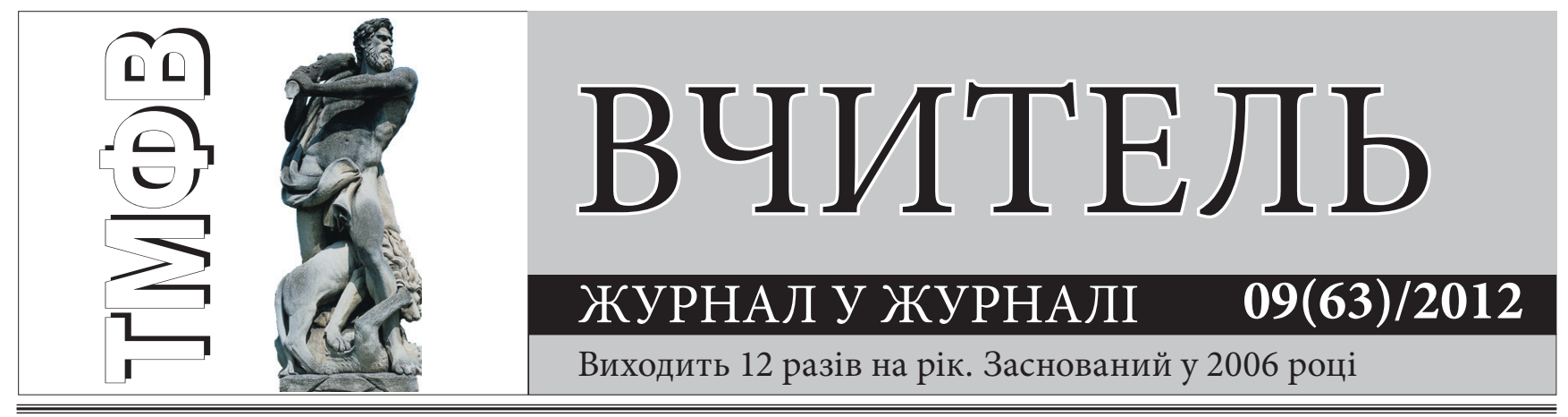

\title{
РОБОЧА ПРОГРАМА 3 ПЕДАГОГІЧНОЇ ПРАКТИКИ В ШКОЛІ (IV КУРС, НАПРЯМ ПІДГОТОВКИ: 6.01020 ФІЗИЧНЕ ВИХОВАННЯ)
}

\author{
Худолій О.М., Іващенко О.В., Карунець Т.В. \\ Харківський національний педагогічний університет імені Г.С. Сковороди
}

Анотація. В статті наведена робоча програма з педагогічної практики в школі за напрямом підготовки 6.01020 фізичне виховання. Робоча програма включає чотири модулі, а також поточний контроль за процесом педагогічної практики.

Ключові слова: студенти, педагогічна практика, фізичне виховання

Вступ. Педагогічна практика - важлива ланка в професійній підготовці майбутнього вчителя фізичної культури.

Організація і проведення практики студентів здійснюється відповідно до галузевих стандартів освіти. Наведена нижче робоча програма упорядкована у відповідності до «Положення про проведення практик студентів вищих навчальних закладів України».

На факультетах фізичного виховання педагогічних університетів накопичений позитивний досвід проведення педагогічної практики, але введення нової Навчальної програми з фізичної культури для загальноосвітніх навчальних закладів 5-9 класи, 10-11 класів вимагає оптимізації підготовки вчителя фізичної культури і відповідно внесення змін до організації педагогічної практики в школі.

\section{Пояснювальна записка}

Педагогічна практика в школі - необхідний етап в підготовці майбутніх фахівців фізичного виховання та спорту.

Педагогічна практика здійснюється на 4 курсі (8 семестр) серед студентів напрямку підготовки «Фізичне виховання» денної форми навчання. Тривалість педагогічної практики складає 5 тижнів.

(c) Худолій О.М., Іващенко О.В., Карпунець Т.В., 2012.
Після проходження педагогічної практики студенти складають залікову документацію. Підсумком проходження навчальної педагогічної практики $є$ диференційний залік.

\section{Мета та завдання}

Основною метою педагогічної практики на випускному курсі є створення єдиної системи знань і практичних навичок для роботи вчителя фізичної культури у школі.

\section{Завдання педагогічної практики:}

- поглиблення і закріплення теоретичних знань, отриманих у вузі, застосування їх на практиці;

- навчання студентів плануванню і проведенню навчально-виховну роботу з урахуванням вікових, статевих та індивідуальних розбіжностей психічного і фізичного розвитку школярів;

- розвиток уміння проводити уроки різного типу, використовуючи при цьому різноманітні засоби, методи і методичні прийоми;

- навчання виконувати функції класного керівника, проводити колективну та індивідуальну виховну роботу, а також виховну роботу з батьками; 
Таблиия 1

Опис навчальної дисиипліни

\begin{tabular}{|c|c|c|c|}
\hline \multirow[t]{2}{*}{ Найменування показників } & \multirow{2}{*}{$\begin{array}{l}\text { Галузь знань, напрям підготовки, } \\
\text { освітньо-кваліфікаційний рівень }\end{array}$} & \multicolumn{2}{|c|}{ Характеристика навчальної дисципліни } \\
\hline & & денна форма навчання & заочна форма навчання \\
\hline \multirow[t]{2}{*}{ Кількість кредитів - 7,5 (6) } & $\begin{array}{l}\text { Галузь знань } 0102 \text { «Фізичне вихован- } \\
\text { ня, спорт і здоров'я людини» }\end{array}$ & \multirow{2}{*}{\multicolumn{2}{|c|}{ Нормативна }} \\
\hline & $\begin{array}{l}\text { Напрям підготовки } 6.0102 \text { Фізичне ви- } \\
\text { ховання, спорт і здоров'я людини }\end{array}$ & & \\
\hline Модулів - 4 & & \multicolumn{2}{|c|}{ Рік підготовки: } \\
\hline Змістових модулів 4 & & 4-й & 4-й \\
\hline $\begin{array}{l}\text { Індивідуальне науково-дослідне } \\
\text { завдання «Аналіз рухової і функ- } \\
\text { ціональної підготовленості шко- } \\
\text { лярів» }\end{array}$ & \multirow[t]{3}{*}{$\begin{array}{l}\text { Професійне спрямування: «Фізичне } \\
\text { виховання» }\end{array}$} & \multicolumn{2}{|c|}{ Семестр 8-й } \\
\hline \multirow[t]{2}{*}{ Загальна кількість годин } & & 270 & 216 \\
\hline & & \multicolumn{2}{|c|}{ Лекції: } \\
\hline \multirow{7}{*}{$\begin{array}{l}\text { Тижневих годин для денної форми } \\
\text { навчання: аудиторних - самостій- } \\
\text { ної роботи студента }-54\end{array}$} & \multirow{7}{*}{$\begin{array}{l}\text { Освітньо-кваліфікаційний рівень: ба- } \\
\text { калавр }\end{array}$} & - & - \\
\hline & & \multicolumn{2}{|c|}{ Практичні, семінарські } \\
\hline & & 180 & 144 \\
\hline & & \multicolumn{2}{|c|}{ Самостійна робота } \\
\hline & & 45 & 36 \\
\hline & & \multicolumn{2}{|c|}{ Індивідуальні завдання: 45 (36) } \\
\hline & & Вид контролю: диферен & ційований залік \\
\hline
\end{tabular}

- прищеплення інтересу до науково-дослідної роботи, знайомство з досвідом роботи вчителів-новаторів;

- ознайомлення і участь у підготовці і проведенні позакласних і позашкільних форм роботи з фізичного виховання школярів;

- набуття умінь самостійно і творчо вирішувати проблеми фізичного виховання унів середніх класів;

- завершення формування основних професійно-педагогічних умінь і навичок.

\section{ПРОГРАМА ПЕДАГОГІЧНОЇ ПРАКТИКИ}

\section{МОДУЛЬ 1. ОРГАНІЗАЦІЙНА РОБОТА}

- участь в настановчій і підсумковій конференціях;

- ознайомлення з адміністрацією, колективом вчителів і матеріальною базою школи, з іiї традиціями і розпорядком;
- участь у чергуванні по школі;

- систематичне складання робочої документації;

- оформлення «Куточка практиканта».

\section{МОДУЛЬ 2. НАВЧАЛЬНО- МЕТОДИЧНА РОБОТА}

- складання індивідуального календарного плану-графіка всієї роботи студента на весь період практики;

- ознайомлення з методикою проведення уроків фізичної культури у закріпленому класі вчителем школи;

- планування навчально-виховної роботи 3 фізичного виховання для учнів закріпленого класу (річне, тематичне і поурочне планування);

- підготовка і проведення щонайменше 8 уроків фізичної культури у закріпленому класі (два з яких залікові) з наступним їх аналізом вчителем, методистом і бригадою студентів;

- вивчення різних форм контролю за рівнем фізичної підготовленості учнів у школі; 
- вивчення впливу вікових і статевих особливостей на зміст, методику і проведення уроку фізичної культури у старшій школі;

- проведення тестування учнів за основними показниками фізичної підготовленості;

- дотримання правил техніки безпеки і страхування на заняттях фізичною культурою;

- уміння застосовувати технічні засоби навчання і нестандартне обладнання;

- уміння узагальнювати передовий педагогічний досвід роботи вчителів і використовувати сучасні форми роботи з фізичного виховання.

\section{МОДУЛЬ 3. ВИХОВНА}

\section{ТА СПОРТИВНО-МАСОВА РОБОТА}

- вивчення класу, за яким закріплений студент, ознайомлення 3 роботою вчителів предметників і класного керівника (бесіди з ними, вивчення їхніх планів роботи, відвідування уроків і позакласних заходів);

- проведення індивідуальної виховної роботи з учнями;

- ведення щоденника педагогічних спостережень;

- організація і проведення виховного заходу у закріпленому класі з наступним його обговоренням;

- ознайомлення із системою різноманітних форм фізичного виховання учнів загальноосвітніх шкіл;

- вивчення принципів відбору для комплектування збірних команд школи з різних видів спорту;

- розробка положення про проведення змагань або сценарію фізкультурного свята;

- проведення занять в одній із спортивних секцій школи;

- ознайомлення з діяльністю і робочою документацією спортивної організації школи;

- ознайомлення з організацією і методикою проведення занять в одній із спортивних секцій;

- участь у підготовці спортивного активу, суддів по спорту.

\section{МОДУЛЬ 4. НАВЧАЛЬНО-} ДОСЛІДНИЦЬКА РОБОТА

- проведення хронометражу уроку фізичної культури;

- проведення пульсометрії уроку;
- тестування рухової і функціональної підготовленості учнів середніх класів;

- проведення педагогічного аналізу уроку фізичної культури;

- аналіз сформованості професійно-педагогічних навичок;

- оформлення результатів досліджень.

\section{Структура навчальної} дисципліни (табл. 2)

\section{Індивідуальні завдання}

Вивчення різних форм контролю за рівнем фізичної підготовленості учнів у школі.

Проведення тестування учнів за основними показниками фізичної підготовленості (див. додаток).

\section{Методи навчання}

Бесіда; робота з книгою; показ; демонстрація; розповідь; опис; пояснення; розбір; завдання; оцінка. Методи контролю - заліковий урок.

Розподіл балів, які отримують студенти (див. табл. 3,4)

\section{дОДАТКИ}

\section{Програма тестування функціональної і рухової підготовленості школярів середніх класів}

Для тестування функціональної підготовленості школярів рекомендуються загальновідомі проби.

Проба Штанге. Учень в положенні сидячи робить глибокий вдих і видих, потім знову вдих (приблизно 80\% від максимального), закриває рот і одночасно затискає пальцями ніс, затримує дихання (секундомір включається в кінці вдиху і виключається з початком видиху). Здорові нетреновані люди здатні затримати дихання на $40-55$ c, ті, які регулярно займаються фізичною культурою і спортом - на 60-90 с і більше. При втомі, перетренуванні час затримання дихання знижується. 
Структура навчальної дисиипліни

\begin{tabular}{|c|c|c|c|}
\hline Види педагогічної діяльності & $\begin{array}{l}\text { Кількість } \\
\text { годин }\end{array}$ & $\begin{array}{l}\text { Організаційні форми виконання за- } \\
\text { вдань }\end{array}$ & Форми звітності \\
\hline \multicolumn{4}{|c|}{ Модуль 1. Організаційна робота } \\
\hline $\begin{array}{l}\text { 1. Знайомство загальноосвітнім за- } \\
\text { кладом. Обговорення графіку вико- } \\
\text { нання всіх видів завдань }\end{array}$ & 6 & $\begin{array}{l}\text { Бесіда } 3 \text { директором, методистом } \\
\text { практики. Самостійна робота }\end{array}$ & Запис у щоденнику \\
\hline $\begin{array}{l}\text { 2. Складання індивідуального плана } \\
\text { роботи студента на період практики }\end{array}$ & 6 & Самостійна робота & $\begin{array}{l}\text { Запис у щоденнику. Відмітка вико- } \\
\text { нання }\end{array}$ \\
\hline $\begin{array}{l}\text { 3. Атестація за } 1-5 \text { тиждень педаго- } \\
\text { гічної практики }\end{array}$ & 10 & Підсумкове зібрання бригади & $\begin{array}{l}\text { Оцінка методиста за звітний тиж- } \\
\text { день практики }\end{array}$ \\
\hline 4. Участь в методичних заняттях & 16 & $\begin{array}{l}\text { Бесіда } 3 \text { методистом факультету. Ви- } \\
\text { конання індивідуального завдання }\end{array}$ & $\begin{array}{l}\text { Оцінка методиста факультету за } \\
\text { звітний тиждень практики }\end{array}$ \\
\hline $\begin{array}{l}\text { 5. Проведення самоаналізу студента } \\
\text { за підсумками практики, оформлен- } \\
\text { ня звітної документації }\end{array}$ & 16 & Самостійна робота & $\begin{array}{l}\text { Звіт } 3 \text { практики, характеристика } 3 \\
\text { бази практики }\end{array}$ \\
\hline \multicolumn{4}{|c|}{ Модуль 2. Навчально-методична робота } \\
\hline $\begin{array}{l}\text { 1. Упорядкування річного плану- } \\
\text { графіку }\end{array}$ & 10 & Самостійна робота & Запис у щоденнику \\
\hline $\begin{array}{l}\text { 2. Упорядкування плану на чверть. } \\
\text { Розробка четверних планів на } 2 \text { кла- } \\
\text { си }\end{array}$ & 10 & Самостійна робота & Запис у щоденнику \\
\hline $\begin{array}{l}\text { 3. Розробка планів-конспектів з фі- } \\
\text { зичної культури розділу учбової } \\
\text { програми }\end{array}$ & 10 & Самостійна робота & $\begin{array}{l}\text { Допуск методиста до проведення за- } \\
\text { няття. Запис у щоденнику }\end{array}$ \\
\hline $\begin{array}{l}\text { 4. Проведення уроків з фізичної } \\
\text { культури в якості помічника вчителя } \\
\text { (1 тиждень по } 18 \text { годин) }\end{array}$ & 18 & Уроки фізичної культури & Запис у щоденнику \\
\hline $\begin{array}{l}\text { 5. Проведення уроків } 3 \text { фізичної } \\
\text { культури в якості вчителя (2-5 тиж- } \\
\text { день по } 18 \text { годин) }\end{array}$ & 72 & Уроки фізичної культури & Запис у щоденнику \\
\hline \multicolumn{4}{|c|}{ Модуль 3. Виховна та спортивно-масова робота } \\
\hline $\begin{array}{l}\text { 1. Складання плану фізкультурно- } \\
\text { оздоровчої і спортивної роботи на } \\
\text { період практики }\end{array}$ & 6 & Самостійна робота & Запис у щоденнику \\
\hline $\begin{array}{l}\text { 2. Розробка документів щодо зма- } \\
\text { гань }\end{array}$ & 6 & Самостійна робота & Запис у щоденнику \\
\hline $\begin{array}{l}\text { 3. Участь в організації і проведенні } \\
\text { фізкультурно-оздоровчих і спортив- } \\
\text { них заходів }\end{array}$ & 24 & Спортивне змагання & Запис у щоденнику \\
\hline $\begin{array}{l}\text { 4. Проведення комплексу вправ, які } \\
\text { використовуються в фізкультурних } \\
\text { паузах та на рухомих перервах }\end{array}$ & 24 & Самостійна робота & $\begin{array}{l}\text { Запис у щоденнику. Допуск мето- } \\
\text { диста до проведення заняття }\end{array}$ \\
\hline \multicolumn{4}{|c|}{ Модуль 4. Навчально-дослідницька робота } \\
\hline $\begin{array}{l}\text { 1. Аналіз сформованості професій- } \\
\text { но-педагогічних навиків }\end{array}$ & 6 & Самостійна робота & Запис у щоденнику \\
\hline $\begin{array}{l}\text { 2. Відвідування уроків, інших форм } \\
\text { позакласних занять вчителів та сту- } \\
\text { дентів }\end{array}$ & 6 & $\begin{array}{l}\text { Педагогічне спостереження, експрес } \\
\text { діагностика }\end{array}$ & Запис у щоденнику \\
\hline $\begin{array}{l}\text { 3. Проведення хронометражу уроку } \\
\text { фізичної культури }\end{array}$ & 6 & Педагогічне спостереження & Запис у щоденнику \\
\hline $\begin{array}{l}\text { 4. Проведення пульсометрії уроку } \\
\text { фізичної культури }\end{array}$ & 8 & Педагогічне спостереження & Запис у щоденнику \\
\hline $\begin{array}{l}\text { 5. Проведення педагогічного аналізу } \\
\text { уроку фізичної культури }\end{array}$ & 10 & Педагогічне спостереження & Запис у щоденнику \\
\hline УСЬОГО: & $270(216)$ & & \\
\hline
\end{tabular}


Розподіл балів, які отримують студенти в процесі поточного контролю на педагогічній практииі

\begin{tabular}{|c|c|c|c|c|c|c|c|c|c|c|}
\hline \multicolumn{3}{|c|}{ Модуль 1} & \multicolumn{2}{|c|}{ Модуль 2} & \multicolumn{2}{|c|}{ Модуль 3} & \multicolumn{3}{|c|}{ Модуль 4} & \\
\hline 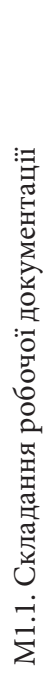 & 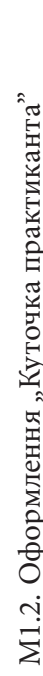 & 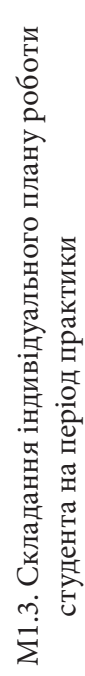 & 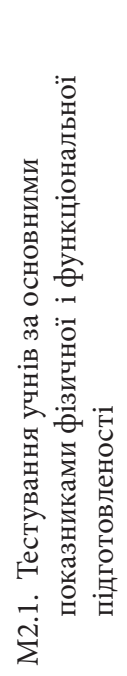 & 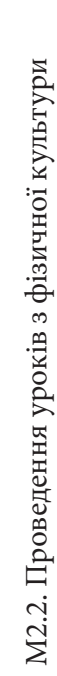 & 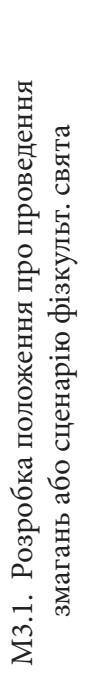 & 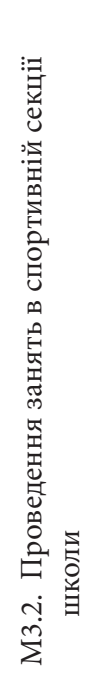 & 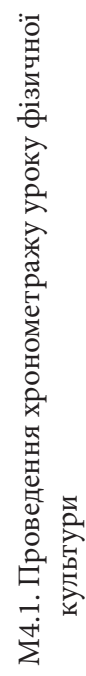 & 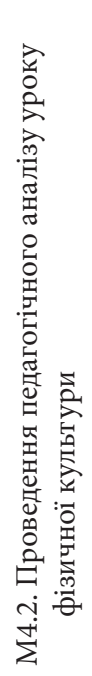 & 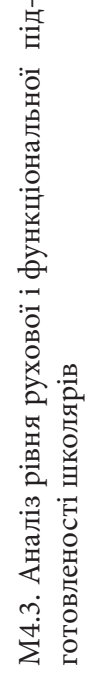 & 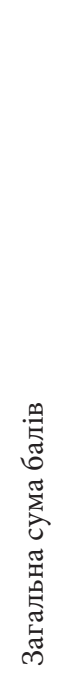 \\
\hline 15 & 5 & 5 & 10 & 30 & 10 & 10 & 5 & 5 & 5 & 100 \\
\hline
\end{tabular}

Шкала очінювання: начіональна та ЕCTS

\begin{tabular}{|c|c|c|c|}
\hline \multirow{2}{*}{$\begin{array}{l}\text { Сума балів за всі види навчаль- } \\
\text { ної діяльності }\end{array}$} & \multirow[t]{2}{*}{ Оцінка ECTS } & \multicolumn{2}{|l|}{ Оцінка за національною шкалою } \\
\hline & & $\begin{array}{l}\text { для екзамену, курсового проекту } \\
\text { (роботи), практики }\end{array}$ & для заліку \\
\hline $90-100$ & $\mathrm{~A}$ & відмінно & \multirow{5}{*}{ зараховано } \\
\hline $82-89$ & $\mathrm{~B}$ & \multirow{2}{*}{ добре } & \\
\hline $74-81$ & $\mathrm{C}$ & & \\
\hline $64-73$ & $\mathrm{D}$ & \multirow{2}{*}{ задовільно } & \\
\hline $60-63$ & $\mathrm{E}$ & & \\
\hline $35-59$ & FX & $\begin{array}{l}\text { незадовільно з можливістю повтор- } \\
\text { ного складання }\end{array}$ & $\begin{array}{l}\text { не зараховано з можливістю повтор- } \\
\text { ного складання }\end{array}$ \\
\hline $0-34$ & $\mathrm{~F}$ & $\begin{array}{l}\text { незадовільно з обов’язковим повтор- } \\
\text { ним вивченням дисципліни }\end{array}$ & $\begin{array}{l}\text { не зараховано з обов'язковим повтор- } \\
\text { ним вивченням дисципліни }\end{array}$ \\
\hline
\end{tabular}

Проба Генчі передбачає затримку дихання після видиху. Її можна проводити не раніше, як через 5-7 хв після проби Штанге. Здорові нетреновані люди здатні затримати дихання на 25-30 с, добре підготовлені фізкультурники - 40-60 с і довше.

Проба Серкіна складається із трьох фаз. Спочатку визначається час затримки дихання на видиху в положенні сидячи, потім учень робить 20 присідань протягом 30 с і повторює затримку дихання, після цього 1 хв відпочиває і знову повторює затримку дихання в положенні сидячи (тобто повторюється перша фаза проби) (табл. 5).

Суттєве скорочення часу виконання проби вказує на погіршення функції дихання, а також кровообігу і нервової системи. При регулярних і вірно побудованих фізкультурних заняттях час затримки дихання повинен збільшуватися.

Проби із затримкою дихання мають низку протипоказань, наприклад, запаморочення, тому їх необхідно проводити з обережністю. 
Таблиия 5

\begin{tabular}{|c|c|c|c|c|}
\hline \multirow{2}{*}{$\begin{array}{l}\text { № } \\
3 / \text { П }\end{array}$} & \multirow{2}{*}{$\begin{array}{c}\text { Контингент дослі- } \\
\text { джуваних }\end{array}$} & \multicolumn{3}{|c|}{ Фази проби } \\
\hline & & Перша & Друга & Третя \\
\hline 1 & Здорові треновані & $\begin{array}{l}60 \text { і біль- } \\
\text { ше }\end{array}$ & $\begin{array}{l}30 \mathrm{i} \\
\text { більше }\end{array}$ & $\begin{array}{l}\text { більше } \\
60\end{array}$ \\
\hline 2 & Здорові нетреновані & $40-55$ & $15-25$ & $35-55$ \\
\hline 3 & $\begin{array}{l}\text { Особи з прихованою } \\
\text { недостатністю крово- } \\
\text { обігу }\end{array}$ & $20-35$ & $\begin{array}{l}12 \text { і } \\
\text { менше }\end{array}$ & $\begin{array}{l}24 \text { і } \\
\text { менше }\end{array}$ \\
\hline
\end{tabular}

Для оцінки рухової підготовленості школярів у період педагогічної практики рекомендуються нижченаведені тести.

\section{1. Стрибки з «надбавками».}

Обладнання. Обладнаний сектор для стрибків; крейда; калькулятор; рулетка.

Проведення тесту. Для кожного учасника тестування визначають максимальний результат у стрибках у довжину з місця. Потім за допомогою калькулятора обчислюють 50 і 75\% максимального стрибка. Креслять на відстані 50\% максимального результату стрибка першу лінію. Для кращого орієнтування збоку встановлюють кубик. На відстані 75\% максимального результату стрибка накреслюють другу лінію. Тим самим визначають індивідуальний коридор стрибків з «надбавками».

Потім у межах даного коридору досліджувані виконують стрибки з «надбавками». Підрахунок надбавок припинявся, як тільки досліджуваний досягнув другої лінії, або якщо у двох стрибках, виконаних підряд, не збільшив довжину стрибка.

Результат. Кількість стрибків з «надбавками», що виконані у заданому коридорі.

Загальні вказівки та зауваження.

1. Виконувати стрибки з жорстким приземленням забороняється.

2. Для визначення максимального результату стрибка надається три спроби. Стрибки з «надбавками» виконуються два рази.

3. Для кращого розуміння виконання тесту надається попередня спроба.

\section{2. Оцінка часових параметрів руху.}

Обладнання. Секундомір.

Проведення тесту. За завданням тестолога випробовуваний виконує біг на місці у середньому темпі, згинаючи коліна до прямого кута між стегном і гомілкою, протягом 5 с. Після цього учасник тестування відтворює тривалість часу бігу -5 с. Тестолог перевіряє правильність відтворення часу бігу за

\section{Зразок 1}

Титульний аркуш

«Затверджую»

Мemoducm

Оиінка

Протокол

тестування функиіональної підготовленості школярів

Дата проведення класу $3 О Ш$ № м. Харкова

Місце проведення

Вчитель

Студент

1. Проба Штанге.

Проби

2. Проба Генчі.

3. Проба Серкіна.

\begin{tabular}{|c|c|c|c|c|c|c|c|c|c|c|c|c|}
\hline \multirow[b]{2}{*}{ № } & \multirow{2}{*}{ ПІБ } & \multirow{2}{*}{$\begin{array}{c}\text { Дата на- } \\
\text { роджен- } \\
\text { ня }\end{array}$} & \multicolumn{2}{|c|}{ Проба Штанге } & \multicolumn{2}{|c|}{ Проба Генчі } & \multicolumn{6}{|c|}{ Проба Серкіна } \\
\hline & & & 1 & 2 & 1 & 2 & 1 & 2 & 3 & 1 & 2 & 3 \\
\hline & & & & & & & & & & & & \\
\hline & & & & & & & & & & & & \\
\hline & & & & & & & & & & & & \\
\hline & & & & & & & & & & & & \\
\hline
\end{tabular}


секундоміром. Потім пропонується зробити те саме протягом 10, 30 і $60 \mathrm{c}$.

Результат. Відхилення, визначене з точністю до 0,1 с, відтворення часового інтервалу. Значення зі знаком «плюс» означає перевищення часового інтервалу, зі знаком «мінус» - недосягнення заданого часу.

Загальні вказівки та зауваження.

1. Учасник тестування неповинен підраховувати час.

2. Виконується тільки одна спроба.

3. Оцінка сприйняття силових параметрів рухів руками.

Обладнання. Кистьовий динамометр.

Проведення тесту. Досліджувані отримують завдання стиснути кистьовий динамометр 3 максимальним зусиллям. Після цього їм пропонується без зорового контролю стиснути динамометр з зусиллям, що дорівнює $1 / 3,1 / 2 \mathrm{i}$ $2 / 3$ максимального. Тест виконується обома руками.

Результат. Оцінюється точність відтворення зусилля, що дорівнювало $1 / 3,1 / 2$ тa $2 / 3_{3}$ максимального (для кожного із досліджуваних воно було індивідуальним). Результат визначається з точністю до 1 кг. Розрахунок нормативів оцінки відхилення відтвореного зусилля визначається у відсотках.

Загальні вказівки та зауваження.

1. Для визначення максимального зусилля досліджувані виконують дві спроби. Реєструється кращий результат.

2. Дозоване зусилля виконується почергово правою і лівою рукою один раз.

\section{4. Човниковий біг $4 \times 9$ м.}

Обладнання. Секундомір і рівна доріжка довжиною 9 м, обмежена двома паралельними лініями. За кожною лінією - 2 півкола радіусом 50 см з центром на лінії. Два дерев'яних кубика $(5 \times 5 \times 5$ см); реєстраційний стіл; стілець.

Проведення тесту. За командою «На старт!» учасник тестування стає у положення високого старту перед стартовою лінією. За командою «Марш!» у максимальному темпі пробігає 9 м до другої лінії, бере один із двох дерев'яних кубиків, що лежать у півколі, бігом повертається назад і кла-

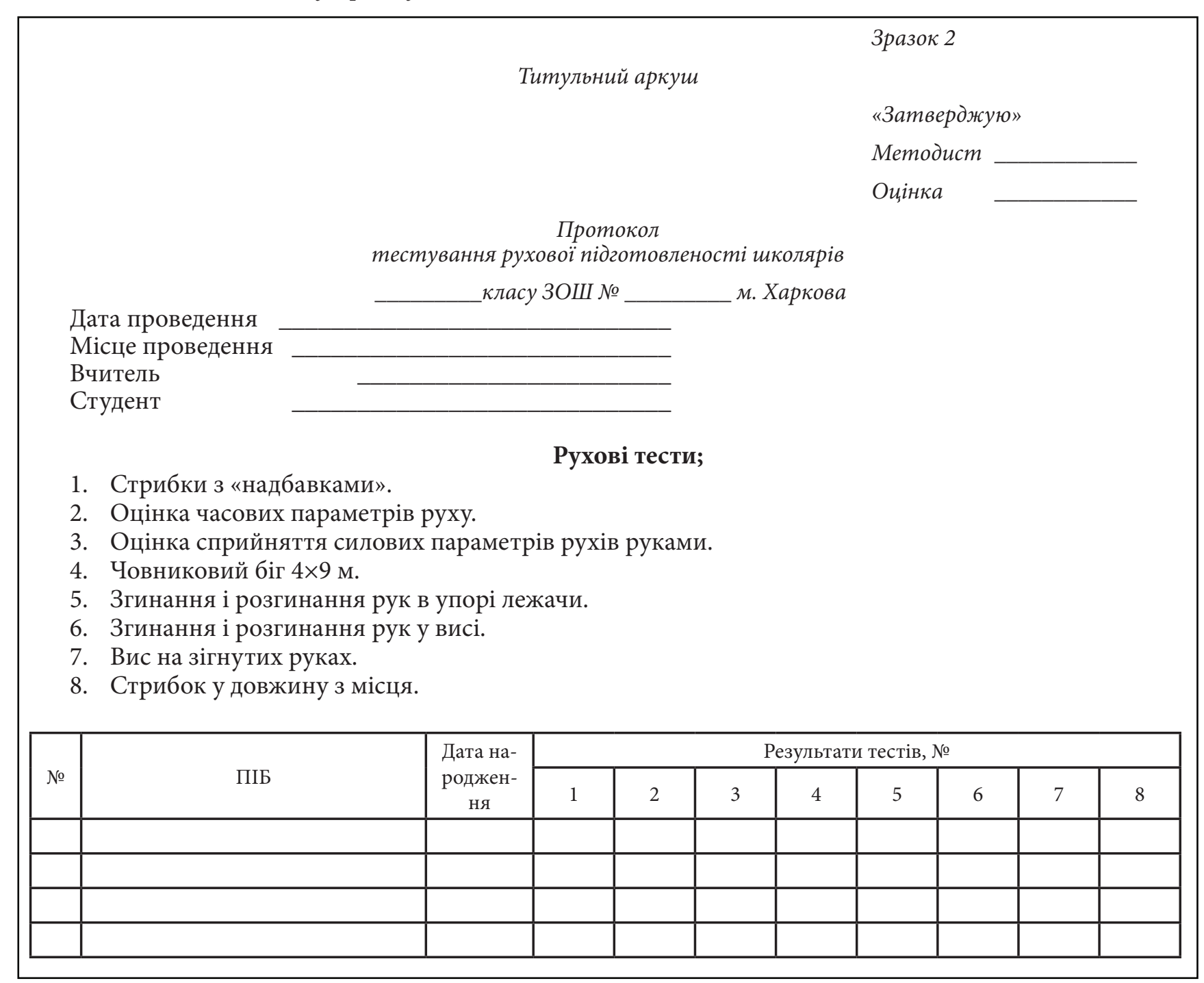


Зразок 3

Педагогічна характеристика функціональної підготовленості учнів

2. Кількість учнів:

клас ЗОШ № м. Харкова

- $\quad$ які не виконують програму з фізичної культури

- які мають низький рівень функціональної підготовленості

3. Особливості планування та проведення уроку відповідно до характеристики класу:

- заходи корекції постави

- заходи щодо підвищення функціональної підготовленості учнів:

4. Відомості про відхилення у стані здоров'я:

\begin{tabular}{|l|l|l|l|}
\hline$№$ 3/п & Прізвище, ім’я & Діагно3 & $\begin{array}{l}\text { Обмеження навантаження на } \\
\text { уроці }\end{array}$ \\
\hline & & & \\
\hline & & & \\
\hline
\end{tabular}

Методист

Студент

\section{Зразок 4}

1. Кількість учнів: хлопчиків
2. Кількість учнів:

Педагогічна характеристика рухової підготовленості

учнів _ клас _ м. Харкова , дівчаток

- які не виконують програму з фізичної культури

- які мають низький рівень координаційної підготовленості

- які мають низький рівень силової підготовленості

3. Особливості планування та проведення уроку відповідно до характеристики класу:

- заходи корекції постави

- заходи щодо підвищення рухової підготовленості учнів:

4. Відомості про відхилення у стані здоров'я:

\begin{tabular}{|l|l|l|l|}
\hline$№$ 3/п & Прізвище, ім'я & Діагноз & $\begin{array}{l}\text { Обмеження навантаження на } \\
\text { уроці }\end{array}$ \\
\hline & & & \\
\hline & & & \\
\hline
\end{tabular}

Методист

Студент

де його в стартове півколо (кидати кубик не можна), знову біжить у зворотному напряму, повертається з другим кубиком і кладе його у стартове півколо. На цьому тест закінчується.

Результат. Час, зафіксований з точністю до 0,1 с з моменту старту до моменту, коли учасник поклав другий кубик у півколо.

Загальні вказівки та зауваження.

1. Кожному учаснику надається дві спроби. До протоколу заносять кращий або середній результат, розрахований із двох спроб.

2. Спроба не зараховується, якщо випробовуваний кидає або впускає кубик у півколо.
Його слід акуратно покласти. Якщо ця вимога не виконується, то надається повторна спроба.

3. Доріжка, на якій проводиться човниковий біг, має бути рівною, у хорошому стані, не слизькою.

5. Згинання і розгинання рук в упорі лежачи.

Обладнання. Рівний дерев'яний або земляний майданчик.

Проведення тесту. Учасник тестування приймає положення упору лежачи: руки випрямлені, на ширині плечей пальцями вперед, тулуб і ноги утворюють пряму лінію, пальці ступнів спирають- 
ся об підлогу. За командою «Можна!» учасник починає ритмічно з повною амплітудою згинати і розгинати руки.

Результат. Кількість безпомилкових згинань і розгинань рук за одну спробу.

Загальні вказівки і зауваження. У згинанні рук необхідно торкатися грудьми опори. Не дозволяється торкатися опори стегнами, згинати тіло і ноги, перебувати у вихідному положенні та із зігнутими руками більше 3 секунд, лягати на підлогу, розгинати руки почергово, розгинати і згинати руки не з повною амплітудою. Згинання і розгинання рук, виконані з помилками, не зараховуються.

\section{6. Згинання і розгинання рук у висі}

Обладнання. Перекладина.

Проведення тесту. Учасник тестування набирає положення вису, руки випрямлені, тулуб і ноги утворюють пряму лінію. За командою «Можна!» учасник починає ритмічно з повною амплітудою згинати і розгинати руки.

Результат. Кількість безпомилкових згинань і розгинань рук за одну спробу.

Загальні вказівки і зауваження. У згинанні рук необхідно наблизитися до точки вису плечима. Не дозволяється перебувати у вихідному положенні та із зігнутими руками більше 3 секунд. Згинання і розгинання рук, виконані з помилками, не зараховуються.

7. Вис на зігнутих руках.

Обладнання. Перекладина, секундомір, гімнастичні мати.

Проведення тесту. Учасник тестування за допомогою набирає положення вису на зігнутих руках, тулуб і ноги утворюють пряму лінію, підборіддя знаходиться вище перекладини. За командою «Можна!» учасник утримує це положення.

Результат. Час у секундах протягом якого утримується вис на зігнутих руках.

Загальні вказівки і зауваження.

1. Виконання тесту припиняється, якщо учень опускає підборіддя нижче перекладини.

2. Хват руками повинен бути на ширині плечей.

8. Стрибок у довжину з місця.

Обладнання. Неслизька поверхня з лінією і розміткою в сантиметрах.

Проведення тесту. Учасник тестування стає носками перед лінією, поштовхом ніг і змахом рук - стрибає вперед якомога далі.

Результат. Дальність стрибка в сантиметрах у кращій з двох спроб.

Загальні вказівки і зауваження. Тестування проводиться відповідно до правил змагань для стрибків у довжину з розбігу. Місце відштовхування і приземлення повинні перебувати на одному рівні.

Резудьтати тестування реєструються у протоколи і на їх основі дається педагогічна характеристика рухової підготовленості школярів (див. зразок $1 ; 2$; $3 ; 4)$.

\section{ПРАВА ТА ОБОВ ЯЗКИ СТУДЕНТА}

Студент має право:

- одержувати консультації вчителя та методиста з усіх питань щодо проведення педагогічної практики;

- користуватися бібліотекою школи, навчальними посібниками;

- вносити пропозиції щодо вдосконалення навчально-виховного процесу, організації педпрактики, брати участь у конференціях та нарадах.

Студент практикант зобов'язаний:

- До початку проходження практики одержати від керівництва практики факультету настанови щодо іiі проходження та оформлення всіх необхідних документів.

- $\quad$ У період педагогічної практики виконувати правила внутрішнього розпорядку школи, розпорядження адміністрації, вчителів та керівників практики. У випадку невиконання пред'явлених до нього вимог, студент усувається від проходження практики.

- Виконувати всі види робіт, передбачених програмою педагогічної практики, старанно готуватися до кожного уроку і позакласного заходу.

- Працювати в школі не менше 6 годин, виконувати індивідуальний план роботи, своєчасно подавати на перевірку документацію (регулярно вести щоденник, подавати конспекти для перевірки і затвердження вчителю та методисту за 2-3 дні до проведення відповідного уроку, здати звітну документацію не пізніше 3-х днів по завершенню практики).

- На період практики один із студентів, який працює в даній школі, призначається старостою групи. В його обов'язки входить облік відвідування студентами школи, повідомлення їх про колективні консультації та семінари, виконання доручень керівників практики.

\section{ПРАВА ТА ОБОВ'ЯЗКИ КЕРІВНИКА ПЕДАГОГІЧНОЇ ПРАКТИКИ}

Керівник педагогічної практики має право:

- брати участь у конференціях та нарадах 3 питань організації і проведення педагогічної практики; 
- вносити пропозиції щодо вдосконалення навчально-виховного процесу, організації педагогічної практики;

- відвідувати загальноосвітні навчальні заклади з метою здійснення контролю за проходженням та виконанням студентами завдань педагогічної практики;

- $\quad$ працювати у роботі комісій при підведенні підсумків педпрактики та вносити пропозиції щодо оцінювання результатів роботи студентів-практикантів;

- $\quad$ пропонувати кандидатуру студента на участь у конкурсі на кращого студента-практиканта. Керівник педагогічної практики зобов'язаний:

- створити належні умови студентам для проходження педагогічної практики та оформлення всіх необхідних документів;

- проводити консультації для студентів з різних питань проходження практики;

- допомагати студентам-практикантам при виконанні ними завдань педпрактики;

- відвідувати загальноосвітні навчальні заклади й заходи, які проводяться студентами, аналізувати їх;

- виконувати всі види робіт, передбачені програмою педагогічної практики.

\section{ЗВІТНА ДОКУМЕНТАЦІЯ ТА ОЦІНЮВАННЯ ПЕДАГОГІЧНОЇ ПРАКТИКИ}

Після завершення педпрактики складається підсумковий звіт.

Для узагальнення матеріалів, зібраних під час педагогічної практики, студентам відводиться 3 дні.

Після завершення педагогічної практики студенти подають керівнику практики:

- письмовий звіт студента про роботу у школі, завірений директором школи;

- $\quad$ протокол обговорення контрольного урока;

- $\quad$ конспекти проведених уроків;

- конспект виховного заходу з позакласної роботи;

- $\quad$ конспект виховного заходу;

- щоденник педагогічної практики;

- матеріали вивчення педагогічного досвіду;

- $\quad$ характеристику студента, завірену директором школи.

Звіт практики захищається студентом (з диференційованою оцінкою) перед комісією, призначеною керівником практики та завідувачами кафедр. До складу входять комісії керівники практики (групові методисти, викладачі кафедри ТМФВ).

Звіт складається упродовж перших 10 днів навчання, яке починається після закінчення педаго- гічної практики. Загальна оцінка роботи кожного студента $€$ комплексною, що враховує всебічність його діяльності за період практики. Оцінка за практику вноситься до заліково-екзаменаційної відомості і до залікової книжки студента з підписами членів комісії, до журналу обліку успішності.

Критерії оцінювання:

- ступінь сформованості професійно-педагогічних умінь;

- рівень теоретичного осмислення студентами своєї практичної діяльності;

- рівень професійної спрямованості та соціальної активності майбутніх вчителів.

Студент, що не виконав програму практики і отримав незадовільний відгук з навчального закладу, де проходив практику, або незадовільну оцінку при складанні заліку, направляється на практику вдруге в період студентських канікул або відраховується з навчального закладу.

\section{ПІДВЕДЕННЯ ПІДСУМКІВ ПЕДАГОГІЧНОЇ ПРАКТИКИ}

Підсумки педагогічної практики підводяться на підсумковій конференції на факультеті. Її завдання: підведення підсумків навчально-виховної роботи практикантів; виявлення досягнень і недоліків у їхній роботі; оцінка рівня теоретичної і практичної підготовленості студентів до навчально-виховної роботи у школі; оцінка якості роботи з організації практики їі керівниками; визначення заходів, спрямованих на подальше поліпшення практики.

Завершальна конференція на факультеті організовується деканатом, кафедрою ТМФВ, кафедрами педагогіки і психології.

Основний зміст підсумкових проблемних конференцій студентів-практикантів складають доповіді з узагальнення досвіду роботи студентів 3 окремих питань організації навчально-виховного процесу в школі.

\section{ЗМІСТ НАВЧАЛЬНОӦ ДІЯЛЬНОСТІ КЕРІВНИКІВ ПЕДАГОГІЧНОЇ ПРАКТИКИ}

Діяльність керівників педагогічної практики - професорсько-викладацького складу університету, керівництва школи та вчителів - здійснюється у 5 етапів: етап попередньої роботи, початковий, основний та підсумковий етапи, етап планової роботи із завершення педагогічної практики.

На етапі попередньої роботи керівники педагогічної практики виконують такі види діяльності: 
- керівник педагогічної практики факультету організовує зустріч методистів, де вони обмінюються досвідом проведення педагогічної практики;

- керівник педагогічної практики факультету проводить заняття з методики проведення педагогічної практики з методистами;

- груповий методист і керівник педагогічної практики від кафедр педагогіки й психології разом $з$ керівництвом школи здійснюють у школі попередній вибір класів, груп, учителів фізичної культури та класних керівників, вирішують інші організаційні питання.

На початковому етапі керівники педагогічної практики виконують такі види діяльності:

- керівник педагогічної практики факультету в перший день педагогічної практики організовує інструктивні збори методистів, керівників від кафедр ТМФВ, педагогіки і психології та студентів факультету;

- груповий методист проводить організаційне заняття з групою студентів в університеті або школі;

- у перший або другий день педагогічної практики в школі проводиться бесіда директора, завуча і вчителя зі студентамипрактикантами;

- у упродовж п'яти днів педагогічної практики організовується знайомство практикантів 3 групами і класами;

- упродовж першого тижня методист організовує відвідування студентами уроків учителів і проводить 3 ними ї аналітичне обговорення;

- $\quad$ у перші дні педагогічної практики груповий методист організовує відвідування студентами (з наступним обговоренням) спеціально підготовленого уроку вчителя, студента або сам проводить показовий урок;

- упродовж перших днів педагогічної практики груповий методист організовує відвідування студентами 3 наступним аналізом позакласного заходу, спеціально підготовленого вчителем, студентом або самим груповим методистом;

- у перший тиждень педагогічної практики організовується знайомство практикантів 3 школярами закріплених класів;

- груповий методист і керівники від кафедр педагогіки і психології затверджують індивідуальні плани роботи студентів-практикантів;

- груповий методист допомагає старості групи студентів-практикантів скласти упродовж першого тижня педагогічної практики загальні розклади уроків практикантів, а також позакласних заходів, методико-педагогічних семінарів, визначити дні самостійної роботи студентів;

- груповий методист подає керівникові педагогічної практики університету загальний розклад уроків, позакласних заходів, взаємовідвідувань практикантами уроків, взаємовідвідувань студентами позакласних заходів та семінарів;

- керівник педагогічної практики факультету аналізує стан початкового етапу педагогічної практики і вживає заходів щодо його покращення.

На основному етапі керівники педагогічної практики виконують такі види діяльності:

- методисти та вчителі консультують студентів $з$ планування серій уроків і складання планів-конспектів окремих уроків, підготовки наочних посібників і технічних засобів, проведення позакласних заходів;

- вчителі відвідують усі уроки закріплених за ними практикантів та аналізують їх;

- методисти відвідують уроки практикантів (не менше трьох уроків кожного практиканта) та аналізують їх;

- після уроку студента-практиканта, на якому були присутні інші студенти, методисти навчають аналізувати уроки: робити загальний, елементний і поглиблений аналіз;

- за необхідністю, методисти дають показові уроки або фрагменти уроків;

- методисти відвідують не менше одного позакласного заходу;

- методист і керівники педагогічної практики від кафедр педагогіки і психології проводять семінари з методики, психології, педагогіки;

- керівник педагогічної практики факультету під час педпрактики відвідує школу: проводить бесіди з керівниками школи, вчителями, знайомиться з документацією, яку ведуть студенти, відвідує уроки та позакласні заходи і бере участь в їх аналізі; бере участь у роботі зборів педагогічного колективу школи за підсумками педагогічної практики;

- керівник педагогічної практики факультету проводить бесіди з груповими керівниками педпрактики про стан педагогічної практики, вживає заходів щодо його удосконалення;

- під час педагогічної практики уроки студентів відвідують представники навчального відділу, деканатів, завідувачі кафедрами, викладачі.

На підсумковому етапі педагогічної практики керівники педпрактики виконують такі види роботи: 
- $\quad$ методист перевіряє документацію, яку ведуть студенти-практиканти, та оцінює іiі;

- методист бере участь в організації та проведенні зборів педагогічного колективу школи за підсумками педагогічної практики;

- $\quad$ на зборах педагогічного колективу школи 3 підсумків педагогічної практики вчителі, класні керівники, методисти та керівники педагогічної практики від кафедр педагогіки і психології характеризують роботу студентів-практикантів.

На етапі планової роботи із завершення педагогічної практики їі керівники виконують такі види діяльності:

- груповий методист перевіряє документацію, яку подали студенти, підписує кожний iii розділ та спільно з керівником від кафедр педагогіки і психології виставляє оцінку за педагогічну практику не пізніше як через три дні після ії закінчення;

- груповий методист і керівник від кафедри педагогіки разом складають короткі характеристики студентів для їх участі у конкурсі на найкращого практиканта, підписують i здають керівникові педагогічної практики факультету не пізніше як за три дні після закінчення педагогічної практики;

- ерівник педагогічної практики факультету вивчає та аналізує звіти групових методистів і документацію студентів, складає звіт про результати педагогічної практики і подає його в навчальну частину університету;

- керівник навчально-виробничої практики університету створює конкурсну комісію, до якої входять декан факультету, керівник педагогічної практики факультету, завідувач секцією факультету кафедри методики, завідувач секцією факультету кафедри педагогіки, групові керівники педагогічної практики, представники з числа студентів. Засідання конкурсної комісії відбувається не пізніше як через 10 днів після закінчення педпрактики. Результати конкурсу доводяться до відома студентів факультету;

- кафедри факультету, педагогіки та психології організовують виставку кращих наочних посібників, виготовлених студентами.

\section{ПІДВЕДЕННЯ ПІДСУМКІВ ПЕДАГОГІЧНОЇ ПРАКТИКИ}

Підсумки педагогічної практики підводяться у кілька етапів: на заключній виробничій нараді у навчальному закладі, де проводилася педагогічна практика, на захисті педагогічної практики і науково-практичній конференції на факультеті, а також на засіданнях кафедр педагогіки, психології, кафедр факультету.

На заключній виробничій нараді в середньому загальноосвітньому навчальному закладі директором затверджуються характеристики студентів-практикантів, складені вчителями і класними керівниками, які працювали із ними. На ній аналізується навчально-виховна робота студентів-практикантів, визначаються позитивні та негативні аспекти іï проходження, висловлюються побажання щодо поліпшення якості педагогічної діяльності майбутніх учителів. У нараді беруть участь студенти-практиканти, вчителі, класні керівники, методисти, керівники практики від кафедр ТМФВ. педагогіки та психології.

Після закінчення педагогічної практики студенти-практиканти складають підсумковий звіт.

На узагальнення матеріалів під час педагогічної практики відводиться 3 дні.

Звітні матеріали, подані студентами, перевіряються і оцінюються викладачами-методистами, викладачами кафедр ТМФВ, педагогіки та психології.

Упродовж перших 10 днів після завершення практики підсумки роботи студентів-практикантів підводяться у формі захисту педагогічної практики. Для його проведення деканатом створюються комісії, очолювані досвідченими методистами, до складу яких входять викладачі з педагогіки та психології, групові методисти. Кожен студент звітує про виконану роботу під час проходження практики, відповідає на запитання, поставлені членами комісії, вносить пропозиції щодо поліпшення підготовки практики, її організації і проведення.

Загальна оцінка діяльності студента-практиканта - комплексна. Вона висловлюється членами комісії, враховуючи оцінки групового методиста, керівників практик від кафедр ТМФВ, педагогіки та психології.

При виставленні загальної оцінки враховується кожен вид роботи:

- $\quad$ навчальна робота з фаху;

- позакласна робота з фаху;

- ведення щоденника (включаючи фіксацію виконаної роботи, аналіз уроків і виховних заходів);

- виховна робота (позакласна робота в прикріпленому класі, якість проведеного залікового виховного заходу і оформлення його методичної розробки, характеристика дана класним керівником);

- психолого-педагогічна характеристика учня (IV курс);

- науково-дослідницька робота в школі; 
- в оцінюванні роботи студентів-практикантів береться до уваги також культура оформлення матеріалів звітної документації;

- якщо студент не виконав хоча 6 одного виду завдань педагогічної практики загальна позитивна оцінка йому не виставляється.

Остаточно підсумки педагогічної практики підводяться на науково-практичній конференції, iіï завданням $€$ :

- підведення підсумків навчально-виховноі роботи студентів-практикантів;

- виявлення досягнень і недоліків в їхній роботі;

- оцінка теоретичної і практичної підготовленості студентів до навчально-виховноі роботи у школі;

- оцінювання якості роботи з організації практики її керівниками;

- планування заходів щодо поліпшення практики.

Основний зміст підсумкової конференції складають доповіді з узагальнення досвіду роботи студентів з окремих питань організації навчальновиховного процесу в школі. В роботі конференції беруть участь працівники інформаційно-методичних центрів відділів освіти, досвідчені вчителі історії та правознавства.

До конференції організовуються виставки наочних посібників, дидактичних матеріалів, кращих матеріалів звітної документації, підготовлених студентами-практикантами під час проходження практики.

На підсумковій конференції оголошується кращий студент-практикант за результатами педагогічної практики.

\section{РЕКОМЕНДОВАНА ЛІТЕРАТУРА}

1. Баскетбол: Учебник для ин-тов физ. культ. / Под ред. Ю.М. Портнова. - М.: Физкультура и спорт, 1988. - 288 c.

2. Вихров К.Л. Футбол в школе / Константин Вихров. - К.: Радянська школа, 1990. - 180 с.

3. Кокарев Б.В. Основи побудови та проведення занять з оздоровчої аеробіки: Навчально-методичний посібник з розділу навчальної дисципліни «Аеробіка» / Б.В. Кокарев, О.Є. Черненко, О.А. Гордейченко. - Запоріжжя: ЗНУ, 2006. - 67 с.
4. Круиевич Т.Ю. Методы исследования индивидуального здоровья детей и подростков в процессе физического воспитания / Татьяна Круцевич. - К. Олимпийская литература, 1999. - С. 30-46.

5. Кузнецов А.В. Спортивные игры и методика преподавания / Алексей Кузнецов. - М.: Физкультура и спорт, 1997. - 268 с.

6. Ланда Б.Х. Методика комплексной оценки физического развития и физической подготовленности: Учебное пособие / Богдан Ланда. - М.: Советский спорт, 2004. - 192 c.

7. Лисицкая Т.С. Аэробика: В 2 т. Т. 1: Теория и методика / Т.С. Лисицкая, Л.В. Сиднева. - М.: Федерация аэробики России, 2002. -232 с.

8. Лисицкая Т.С. Аэробика: В 2 т. Т. 2: Частные методики / Т.С. Лисицкая, Л.В. Сиднева. - М.: Федерация аэробики России, 2002. $-215 \mathrm{c}$.

9. Романенко В.А. Диагностика двигательных способностей. Учебное пособие / Валерий Романенко. Донецк: Изд-во ДонНУ, 2005. - 290 с.

10. Сватьєв А.В. Функціональна діагностика у фізичному вихованні і спорті: Навчальний посібник для студентів вищих навчальних закладів / А.В. Сватьєв, М.В. Маліков. - Запоріжжя: ЗДУ, 2004. - 195 с.

11. Теория иметодика физического воспитания:Учеб. для студентов фак. физ. культуры пед. ин-тов по спец. 03.03 «Физ. культура» / Б.А. Ашмарин, Ю.А. Виноградов, 3.Н. Вяткина и др.. - М.: Просвещение, 1990. - 287 с.

12. Теория и методика физического воспитания: Учебник для студ. физ. воспитания и спорта: В 2 т./ Под ред. Т.Ю. Круцевич. - Т.1.: Общие основы теории и методики физического воспитания. - К.: Олимпийская литература, 2003.- 424 с.

13. Теория иметодика физического воспитания: Учебник для студ. физ. воспитания и спорта: В 2 т./ Под ред. Т.Ю. Круцевич. - Т.2.: Методика физического воспитания различных групп населения. - К. Олимпийская литература, 2003.- 391с.

14. Холодов Ж.К. Теория и методика физического воспитания и спорта: Учеб. пособие для студ. высш. учеб. заведений. - 2-е изд., испр. и доп. / Ж.К. Холодов, В.С. Кузнецов. - М.: Издательский центр «Академия», 2002. $-480 \mathrm{c}$.

15. Худолій О.М. Основи методики викладання гімнастики. Том 1,2: Харків: ОВС, 2008. - 408 с.

16. Худолій О.М. Загальні основи теорії і методики фізичного виховання. - Харків: ОВС, 2008. - 406 c.

17. Шиян Б.М. Теорія і методика фізичного виховання школярів. Частина 1 / Богдан Шиян. - Тернопіль: Навчальна книга - Богдан, 2006. - 272 с.

Надійшла до редакиії 26.11.12p.

Худолей О.Н., Иващенко О.В., Карунец Т.В. Рабочая программа из педагогической практики в школе (IV курс, направление подготовки : 6.01020 Физическое воспитание).

В статье приведена рабочая программа из педагогической практики в школе за направлением подготовки 6.01020 физическое воспитание. Рабочая программа включает четыре модуля, а также текущий контроль за процессом педагогической практики.

Ключевые слова: студенты, педагогическая практика, физическое воспитание.

Khudolii O.M., Ivashenko O.V., Karpunec T.V. Executable code from pedagogical practice at school (IV course, direction of preparation : 6.01020 P.E.).

To the article an executable code is driven from pedagogical practice at school after direction of preparation 6.01020 P.E. An executable code includes four modules, and also current control after the process of pedagogical practice.

Keywords: students, pedagogical practice, P.E. 